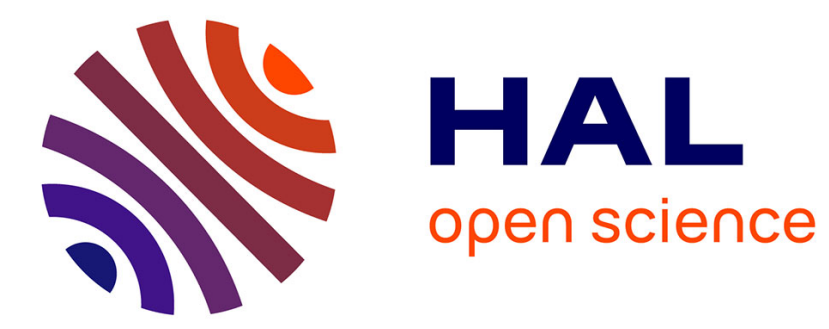

\title{
Texture analysis by a perceptual model
}

\author{
Isabelle L. Herlin, Jean-Pierre Crettez
}

\section{To cite this version:}

Isabelle L. Herlin, Jean-Pierre Crettez. Texture analysis by a perceptual model. International Conference on Pattern Recognition (ICPR), Nov 1988, Rome, Italy. pp.764-766, 10.1109/ICPR.1988.28352 . hal-01307039

\section{HAL Id: hal-01307039 \\ https://hal.inria.fr/hal-01307039}

Submitted on 26 Feb 2021

HAL is a multi-disciplinary open access archive for the deposit and dissemination of scientific research documents, whether they are published or not. The documents may come from teaching and research institutions in France or abroad, or from public or private research centers.
L'archive ouverte pluridisciplinaire HAL, est destinée au dépôt et à la diffusion de documents scientifiques de niveau recherche, publiés ou non, émanant des établissements d'enseignement et de recherche français ou étrangers, des laboratoires publics ou privés. 


\section{Texture Analysis by a Perceptual Model}

Isabelle L. Herlin

INRIA

Rocquencourt, BP 105

78153 Le Chesmay Cedex, FRANCE
Jean-Pierre Crettez

LAFORIA-Paris6

4,place Jussieu

75005 Paris, FRANC,

\begin{abstract}
A hierarchical set of operators for texture analysis is presented. (1)il method is to code the local frequency resonance of these "petalors but not their simple responses. Therefore, the texture leatures olstained are stable. The operators fultill the conditions les riled hy J.P. C'rettez in his work un the visual system model Th. procedure is used to automatically determine the resolution if homogeneus texture, the resolution being the minimum windiw stae capable of giving stationary features. All the samples in initable size then have the same signat ure coding the local le.dure of texture.
\end{abstract}

Keywords:texture, resolution, texture discrimination.

\section{Introduction}

Tixture is the term generally used to characterize a region in .11 $1111.1 \mathrm{ge}$, corresponding to a homogenrous local spatial orga11zatıu. Texture is a perceptual concept for which there is in. m.thematical definition |5|. Perceptually, texture gives the attic visual impression for any position of a small window of ., hervation inside the corresponding region $|4|$. For any posiI 101 in the visual axis, the neuronal responses of cortical cells

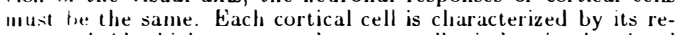
" pplive held which corresponds to a small window in the visual hell ('onsequently, a texture must be analysed by small lo.1 1 rimples. Samples of a homogeneous texture should give the - ame response. A simple corresponds to a pixel neighborhood. 1 inminer of analytical methods, which all try to characterize pixet II"Ighhorhood relationships, have been proposed during last decalde. Recently, linser developed the use of textural measures bantin the average of some local properties |7|. Local textulal properties are extracted in two stages: a local linear process followed hy a non-linear process. The statistics of the individual Ians-lorm coefficients are then used as texture descriptors. By analogy with the receptive field models for simple or complex (.)lls iin the visual areas, we present, in this paper, a set of textuse uperaturs $|2||3|$. These operators can be efficiently applied 16 1.exiures by the aid of Hadamard Transform and by an oper.tion which makes results of operators invariant by translation inl homsgeneous textures.

\section{Texture Feature Extraction}

\section{2-1 The Set of Operators}

II nenatur or a filter simulates a single cell of a visual sys1...1. So the neighborhood geometry, on which the uperator is appliced, models the reception held of the cell, while the cuefth ient: of the operator or filter simulate the cell responses in vivill visual stimula. Due to hierarchy, the first order operators are -imply ruadruplets in liexagunal tesselation. The coefficients ale- ollduined from Hadamard matrices $H_{4}$ : every line of the ma11 ix prove the cueflicients of one filter. We have then four filters, - allal lin-t-order wperator:s or lirst-order filters, represented in tran. 1. The meighborlood structure of the second-order is obtane. lrom that ol the first order: dilating twice the first order's -111111110 and replacing each point by the structure of the lirst .1.l.1 Sin a second-order structure includes 16 pixels and is rep....11..1 in hgure 2 More generally, an n-th order structure . ai I. in indued by dilating twice the (11-I)-st order structure an. Inplumg each point by the structure ol the first order. A
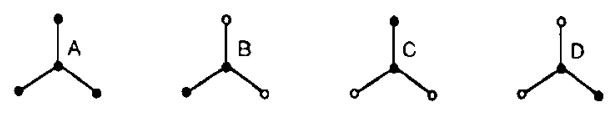

$\bullet=+1$

$0=-1$

Figure 1: first-order operators

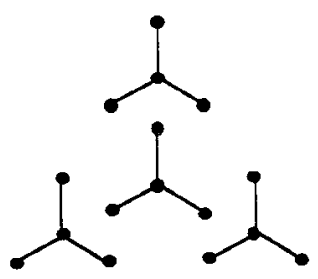

Figure 2: structure of second-order operator

second order operator corresponds to a line of the Hadamard matrix $H_{16}$, and a $n$-th order operator corresponds to a line of the Hadamard matrix $\mathrm{H}_{4} \mathrm{n}$. So the connection process between the different order structures can be modelled by the Hadamiard Transform $H_{4}$ in the natural order.

\section{2-2 Properties of the Operators}

We suppose that our operators model the simple cells of the striate cortex. As shown in figure 3, the first-uider operaturs are uriented filters. We want to know if the operators of higher order can also analyse the orientations and frequencies. This can be determined from the operators orientation-frequency properties by use of the fourier Spectrum.

We consider every operat or as an image and periodize it in the image space. We then apply the Fourier Transtorm and look for the maxima of the power spectrum

We can make a drawing of the Fourier plane for every order and mote the pusitions of the maxima:

- for the first and second order we obtain an unifon mu sanpling of the fourier space

- for higher orders we must use the secondary maxima Fiom the secund erder it is possible to see that sinte (opesators have the same puwer :pectrum. They difler only hy phase. They 
$z^{\prime}$ is the summation of the geometrical response of the operator 2. This summation permits us to avoid local noise and to extract global propert ies of texture.

\section{Resolution and Invariance}

Our procedure is used to automatically determine the resolution of a homogeneous texture: the minimum window size giving an invariant translation perception. A number of textures are considered.

J denotes the window

a denotes the operator

F denotes the width of the window

$m n^{\prime \prime}$ and $\sigma^{\prime \prime}$ are the mean and the standard deviation of the results of operator a for windows of width $p$.

We define the following criterion :

$$
\left(l^{\prime}\right)-\sum_{1=2}^{111} \sigma_{1} / m_{1}
$$

When p increases, ('(p) temds to a limit:

$$
\underset{\gamma+2}{\lim }\left(f^{\prime}(p)=\right.\text { cortst }
$$

We choose the value where the criterium is stable enough

$$
|(\nu) \underset{(\nu)}{(\cdot(\nu+1)}|<=
$$

This value, denuted $P$, is called the mathematical resolution of the texture.

Experimentats results show that this corresponds to the perceptual resolution of the texture. The perceptual resolntion of the texture is the window width that gives a translation-invariant perception. By considering for une texture a number of samples with the correct width P', we have shown that the unuerical sample signatures are very stable and permit a good classification rate (6)

A secund phase, described below, permits us to ubtain constant signalure vectors.

For every operator, 2 , we cunsider the mean $m$ of the results of that operator for winclows of suitable width. We represent the $m$, graphically hy ordering them in decreasiug order

Two cases are possible

The first case is represented in figure 4. The curve presents an (lieighborhood at location $(k, l)$. This set is reordered .hlain a nine binary components vector $I_{k,}=\left(u^{2}, u^{3}, \ldots, u^{10}\right)$ where.

- $u^{2} 1$ if the operator, $\imath$, gives a response that is a local maxianmar of thas frequency representation

- $u^{\prime}$ () otherwise.

The first operator is not considered, because the response ( summation of the grey levels) is always a maximum in the frequency ropresentation. We decided to consider only the geometry of the frequency representation to be coherent with the perceptual lala. Ry comparing the responses of the operators in the Fourier replandition, we model the excitation-inhibition phenomenis leelweell visual cells of same urder.

\section{2-4 Texture Signature}

We comsider that a texture sample is a $\mathrm{NxN}$ subimage. For evers location $(k, l)$ in the sample, we calculate the nine binary cominntients vector $I_{\lambda, 1}$. We sum up $I_{h, 1}$ over the subimage to il, atil the sample signature $Z$

$$
Z-\sum_{h}^{N} \sum_{l}^{N} l_{h}
$$

If $/$ i. lenoted: $Z \cdots\left(z^{2}, \ldots, z^{\prime \prime \prime}\right)$ we oltain:

$$
z^{\prime} \quad \sum_{1}^{N} \sum_{1}^{N} u_{i}^{n}
$$

Figure 4: first type of means curve

important variation alten the k-th number (in figure $k$. 3) nances. We say that the texture presents $k$ important frequential reso- 
'The'l we code the signature vector ' $Z$ ' with the following method

Ihe $h$ hreatest components of $Z^{\prime}$ are coded by 1 and the other idlue are coded by 0

Whe whidin a new vector $Y^{\prime \prime}$.

$Y$ ' is alled the signiat ure vector of the sample $\mathrm{j}$.

The stcond casc is represented in figure 5 . The mean curve

mean

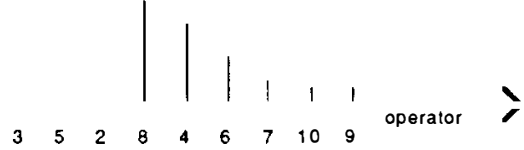

Figure 5: second type of means curve

1, 1 - a a - antinumm of values. We cunsides

$$
M \quad \sum_{9}^{Y, 1}\lfloor m\rfloor \mid
$$

If. sal that an operator 2 presents an important. resonance on

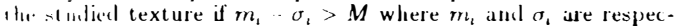
tively the mean and the standard deviation resulting from the Ip plic it ion of the operat or :

If $k$ operators satisfy this property we say that the texture phent: $k$ inportant frequential resontances. The final signaIIr. vinctor $Y^{\prime}$ is sociated to the vector $Y^{\prime}$ is defined as above. Iut experinents have shown that this new signature vector is (11..1.14l wilh translation.

\section{Application and Results}

Pho glubal procedure has been used on different nat ural textures .rotialed ficm Brodiate's textures. For every texture we have hri-1 delermined the resolution.

A. hive then observed 100 samples of suitable width for every 1, xlun and examined the signature vectors. The results are rxperesed in the following table.

lho lunal line gives the name of the texture. The second line gives 1ha. Inaliematical resolution of the texture. The lines three to - Hevell give the resnlts of the operators for the different textures. Hhe operator 1 is not considered becanse its response is always 1 111.18/11mun and its value is always 1 .

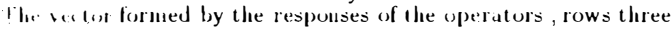
1... l. v. .u, is the signature of each texture. Almost all the samples have l he sane signature. The last line gives the number of errors 1., the different textures

\begin{tabular}{|c|c|c|c|c|c|}
\hline $\begin{array}{l}\text { testure } \\
\text { waridowwilth }\end{array}$ & $\begin{array}{l}\text { wored } \\
\text { ชn }\end{array}$ & $\begin{array}{l}\text { Jute } \\
\text { tj4 }\end{array}$ & $\begin{array}{c}\text { wool } \\
56 i\end{array}$ & $\begin{array}{c}r r \in p i l \\
56\end{array}$ & $\begin{array}{c}\text { liviken } \\
80\end{array}$ \\
\hline "fieruter 2 & 1 & 0 & 1 & 1 & 0 \\
\hline oferator 3 & 0 & 1 & 1 & 1 & 1 \\
\hline 1)erutor 4 & 1 & () & 1 & 1 & 0 \\
\hline iferutor 5 & () & 0 & 0 & () & () \\
\hline uperalt, 6 & () & 1 & 0 & I & 0 \\
\hline . prerator 7 & (1) & () & 0 & i) & () \\
\hline uferatur 8 & 1 & 0 & 0 & () & () \\
\hline "ferutury & 0 & 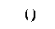 & $u$ & 0 & 0 \\
\hline .pitratior 10) & 0 & I & () & 0 & 0 \\
\hline crritss & 0 & 5 & u & 1 & 0 \\
\hline
\end{tabular}

\section{Stability of the Results}

The signature vecton that we obtain is very stable. The property of transfation-invariance requires large window width to calculate signature vectors, but in fact we need unly a few points inside the window

The study of stability wis done wilh two textures: wood and woven. We have computed the immlier of errors to translatiuninvariance when we calculate the local caracterization of texture only at $\mathbf{N}$ points inside the window. The chuice of the $N$ points inside the window is done wit li a random procedure. The results are expressed by the following tables. The first line gives the number of points inside the window, where the texture caracterization is done.

The secund line gives the number of errors.

This study is done with 100 samples for every texture.

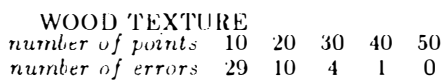

WOOL TEXTURE

$\begin{array}{llcccc}\text { number of points } & 100 & 160 & 220 & 280 & 340 \\ \text { number of errors } & 11 & 13 & 4 & 4 & 0\end{array}$

These two textures were chusen because they exhibit different behaviors when we perform the texture characterization on a few points inside the window. The stability converges faster with the wood texture. The conclusion is identical: we don't need to calculate the texture characterization at every pount, but at most at 25 percent of points.

\section{Conclusion}

By using a linear transform over a neighburhood and a nonlinear process, we obtain a texture signature that call be used to define the resolution of an homogeneous texture image. This process can be used to find the homogeneous textured regions in an image and, more generally, for segmentation.

\section{References}

(1) P. Brodalz. Textures: a Photograph Album for Artists and Designters. Dover, New-York, 1956

2) J.P. Crellez. Mudélisation des Voies Visuelles Primaires Premiern: bitapes de la Perception des Formes. Thise d'Ftat, Paris 6, 1984

13) J.P. (rettez and J ( $\therefore$ Simon. A Model for Cell Receptive Fields in the Visual Striate Cortex. In ('omputer Ciraphics and Inage Processing, 20, pages 299-318, 1982.

|4 A. Ciagalowicz and S. De Ma. Seguential Synthesis of Natural Textures. In Computer Vasion, Graphacs and Image Proctss. ing, 30, pages $289315,1985$.

(5) R.M. Haralick. Textural Feature for Image ('lassification. In IEEE Transactions on System, man and cyber., pages olo. $621,19865$.

(6) I.L. Herlin and Y. Xia. A Set of Operators for Texture Analysis. In Procetdings IASTED'86, Italy, pages 142,144, 1986.

17 M. Unser. Locial Linear Transforms for Texture Measurements. Sirynal Processang, 11, paiges61 79, 1966 